\title{
Current and Functional Reactor Designs in Poultry Slaughterhouse Wastewater Treatment
}

\author{
Derrick N. Dlamini ${ }^{\mathrm{a}, \mathrm{b}}$, Moses Basitere ${ }^{\mathrm{a}, \mathrm{b}}$, and Seteno Karabo O. Ntwampe
}

\begin{abstract}
Poultry slaughterhouse industry consume high volume of portable water and generate large volume of wastewater which contain high Chemical Oxygen demand, Total suspended solids, fats, oil and grease (FOG). In order to mitigate the disposal of raw poultry slaughterhouse wastewater (PSW) effluent, various technologies such as chemical-DAF, electrocoagulation, EGBS and UASB reactors have been used to treat the PSW. However, most of these technologies have operational challenges which range from clogging of reactors, long processing time and low efficiencies. This paper aims to highlight challenges faced during operation of these reactors and also motivate for design improvement to mitigate the deficiency.
\end{abstract}

Keywords-Chemical oxygen demand (COD), Fats oil and grease(FOG), Poultry slaughterhouse wastewater(PSW), Static granular bed reactor(SGBR).

\section{INTRODUCTION}

Poultry slaughterhouse wastewater (PSW) is generated from bird slaughtering, de-feathering, bird washing, deboning and bird trimming activities [1]. Furthermore, poultry wastewater also consists of high FOG which is of great concern for anaerobic digestion technology. The nature of the activity, poultry processing, is connected to the use of water during washing and poultry processing which in turn releases tremendous amount of volume of wastewater in the process. In South Africa, the poultry industry has been identified among the highest generator of wastewater which to a limited extent gets subjected to regulatory practises and control of waste-water generation and disposal [2]. Wastewater generated during poultry processing contains solid soluble matter due to the presence of fats oil and grease (FOG) [3]. Ordinarily, poultry slaughter wastewater is firstly pre-retreated using the conventional methods before it gets charged into a bioreactor for further processing. Industrial pre-treatment coupled with an aerobic biological process has been found to be beneficial [4]. There are a number of wastewater treatment methods that have been explored in the treatment of PSW. One of the previous methods that have been studied to a less extent, is the biological pre-treatment system coupled with static granular bed reactor (SGBR). The SGBR is a reactor which has no mixing mechanism but rather it has a down-flow system fitted with static granules and sludge which serve as a biodegrading medium. Generally, SGBR reactors have a wide range of

\footnotetext{
${ }^{\mathrm{a}}$ Department of Chemical Engineering, Cape Peninsula University of Technology, P. O. Box 652, Cape Town 8000, South Africa,

${ }^{\mathrm{b}}$ Bioresource Engineering Research Group (BioERG), Department of Biotechnology, Cape Peninsula University of Technology, P. O. Box 652, Cape Town 8000, South Africa,
}

advantages which include the simplicity of operation and the production of high quality effluent [5]. This paper focussed on a novel process which will use a biological pre-treatment process which is coupled with the SGBR reactor.

\section{BiologiCAL ENZYMES IN WASTEWATER TREATMENT}

Biological enzymes are protein catalysts that speed up a reaction without being used up [6]. Biological additives employed in wastewater treatment have been found to have significant beneficial impacts and do not harm onsite systems [7]. According to Tang \& Tong [7], 'Garbage enzyme' was experimented in the treatment of domestic wastewater and it was found to have raised the wastewater biological oxygen demand (BOD) in proportion to its dilution due to its high content. A majority of enzymes used in wastewater treatment belong to the category of biological additives. Moreover, an enzyme called 'pancreatic lipase' was used for hydrolysis and to reduce FOG in slaughterhouse wastewater [8], and it reduced a high amount of pork fat in the pre-treatment step. The latter, 'pancreatic enzyme', was isolated from a pig pancreas which contains lipase, some small amounts of amylase and protease which are primarily used in the hydrolysis of carbohydrates and protein. The 'pancreatic enzyme', was isolated from a pig pancreas which contains lipase, some small amounts of amylase and protease which are primarily used in the hydrolysis of carbohydrates and protein. There are a few studies that have been pursued when it comes to biological pre-treatment of PSW so far. When enzymes are employed in the pre-treatment of PSW effluent, the triglycerides are hydrolyzed to fatty acids and glycerol, and this leads to faster and efficient biodegradation of fat by microorganisms [9]. Biosurfactants has reportedly been studied in the treatment of wastewater as well. Biosurfactants are biomolecules that are produced by microorganisms and can also be used in the treatment of PSW effluent. An evaluation of a biosurfactant, obtained from cassava wastewater, used in the treatment of PSW effluent yielded an oil and grease removal efficiency of above 70\% [10]. The use of biosurfactants has proved that biosurfactants have good properties which are biodegradable, digestible and biocompatible which make them appropriate for treatment of industrial wastewater [11]. Advantages of biosurfactants are enormous as compared to synthetic surfactants and they are generally considered to be less or non-toxic. A study of a biosurfactant called 'LGP' was conducted in comparison with a chemical surfactant called 'Finasol', the biosurfactant proved to be 3 times lower in terms of toxic levels [12]. Furthermore, most biosurfactants are not affected by adverse environmental factors such as $\mathrm{pH}$ and temperature. Bio-emulsifiers isolated at $\mathrm{pH}$ range of (5-10) and 
temperature of $80^{\circ} \mathrm{C}$ were found to be effective in the treatment of wastewater [13]. In terms of availability, biosurfactants have been found to be easily obtainable in large amounts and are very cheap. A pilot plant and large scale of bioremediations of soil contaminated with hydrocarbons and oil was used a source of biosurfactants [14]. There is still a need for exploring different type of enzymes or bacteria that may be used in PSW treatment.

\section{TYPES OF WASTEWATER PRE-TREATMENT PROCESSES}

Pre-treatment is the preliminary removal of sludge material such as fats, oil, grease, and other various solid matter contained in the PSW effluent. Pre-treatment processes can either be physical, chemical, and biological to mention but a few, which are mainly used to remove contaminants contained in PSW effluent. Biological processes are processes where living microbial organisms are used [15], chemical processes involve the addition of chemicals like coagulant [16]. Physical processes would refer to conventional process that mainly utilize screens of different aperture sizes, fat traps and grit chambers for removal of larger particles in a conventional method [17].

\section{A. Conventional Pre-treatment Methods}

In conventional pre-treatment processes, the influent passes through a screen in order to remove large objects. Typically, screen aperture sizes for coarse particle removal is $+6 \mathrm{~mm}$ and for fine particle removal is 1,5 to $6 \mathrm{~mm}$ [18]. After the influent has been screened it then passes onto a grit chamber where the sand and small stones settle at the bottom and are then removed. The removal of grit normally prevents wear and tear of the equipment. At this point, it must be borne in mind that the influent from the grit chamber still contains a substantial amount of organic matter and suspended solids. These biosolids are then removed in a sedimentation tank where they are first allowed to settle at the bottom when the flow rate of water is reduced. A study of inorganic suspended solids removal from wastewater by using a grit chamber yielded a COD removal efficiency of $5.2 \%$ and a total suspended solids (TSS) of $12.6 \%$ [18]. Problems of screen blockage may arise when treating PSW effluent by conventional pre-treatment method, so this type of method is not recommended.

\section{B. Physico-Chemical Pre-treatment Methods}

Generally, it is recommended that the effluent processed from the preliminary treatment is passed on to a subsequent primary and secondary treatment for further processing depending on the strength of the PSW. A physicochemical process employed in wastewater treatment is done so with the intention of removing suspended solids and fats, oil and grease prior to the secondary treatment process. Below is a list and discussion of commonly used physicochemical methods.

\section{1) Dissolved Air Floatation (DAF)}

The dissolved air flotation (DAF) process is a method whereby liquid-solid separation typically happens by dissolving air in wastewater under pressure [20]. A DAF system was reported in a study of the treatment of PSW with a surface loading rate of $1.6 \pm 0.4 \mathrm{~m}^{3} / \mathrm{m}^{2}$, yielded a removal efficiency of oil and grease of $51 \pm 16 \%$ and suspended solids of $37 \pm 16 \%$ [21].

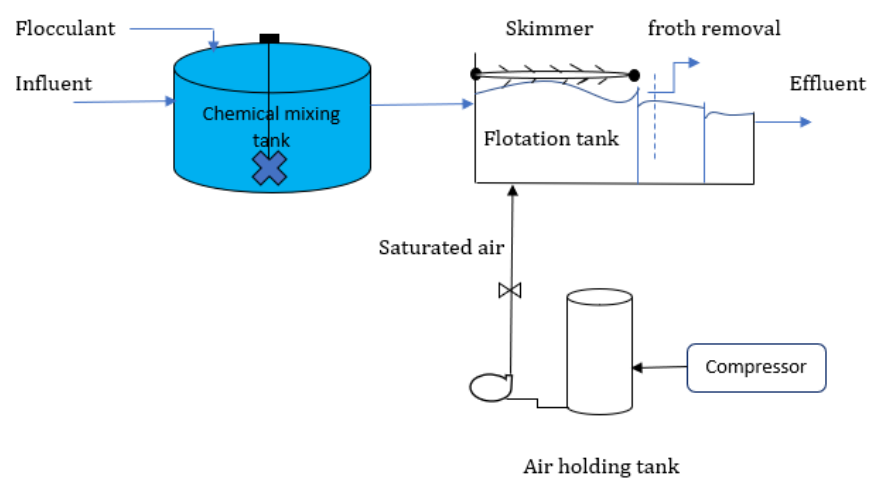

Fig. 1. Schematic diagram for chemical-DAF.

\section{2) Coagulation and Flocculation}

Coagulation and flocculation pre-treatment of PSW effluent makes use of chemical reactants such as flocculants and coagulants to separate suspended and dissolved solids from water. Coagulants destabilize particles because they have opposite charges to those of suspended solids, and flocculants prompt the destabilized particles to conglomerate into larger particles called flocs [22]. In another study of physicochemical treatment of PSW effluent using lime, alum, ferrous sulfate and anionic polyelectrolyte as coagulants was performed. The results yielded a removal efficiency of BOD, COD and SS up to $38.9 \%, 36.1 \%$ and $41.9 \%$ [23].

\section{3) Electrocoagulation}

Electrocoagulation used as a pre-treatment method, removes suspended solids and other contaminants through the inducing of an electric current together with the addition of chemicals. The induced electric current changes the suspended solids surface charge thereby allowing the particles to form an agglomeration. A study of examination of electrocoagulation treatment of PSW by investigating the effects of electrode material, $\mathrm{pH}$, and current density on the COD and FOG removal, was performed. The highest COD removal was reached with aluminum $(\mathrm{Al})$ electrodes at $93 \%$ and the highest FOG removal was reached with iron $(\mathrm{Fe})$ electrodes at $98 \%$ [24]. Electrocoagulation is not a cheap process in its nature because of high electricity costs and as well as expensive metal plates. Even though this process has proven to be effective, it would be interesting to see results of the process if it were to be operated at higher temperature that ambient.

\section{BIOLOGICAL PRE-TREATMENT METHODS}

Biological pre-treatment is ordinarily used as a secondary treatment step, but it may also be used as a primary pre-treatment step. Microorganisms are used in biological treatment processes in order to remove organics and pathogens contaminants. Moreover, typical microorganisms used in such a process would include, fungi, bacteria and/or algae. There are different types of biological treatment processes, which include but are not limited to, anaerobic, aerobic, activated sludge and combined processes. 


\section{A. Anaerobic Treatment of Poultry Wastewater}

The anaerobic treatment process is a technique which is widely used in the treatment of high strength poultry wastewater [25]. There are advantages that come with the use of anaerobic treatment processes which range from low electricity costs, high throughput of biogas, less sludge generation, and high organic matter removal [26]. An evaluation of the performance of an up-flow anaerobic filter (AF) was used in the treatment of wastewater. The study reported a COD and BOD removal efficiency of $81 \%$ and $87 \%$ with a 15 days period [27]. In another study of the treatment of PSW effluent by using an anaerobic UASB with a hydraulic retention time (HRT) of 1 day, removal efficiencies of up to COD of 70\%, BOD of $73 \%$, and FOG of 35\% were obtained respectively [28]. Yousefi [29] conducted a study of treatment of PSW effluent by using a combined anaerobic system of 3 pilot-scale anaerobic baffled reactors $(\mathrm{ABR})$ in the first stage, followed by 3 anaerobic filters (AF). An evaluation of the ABR reactor used in the latter study showed a COD removal efficiency of $83 \%$ after an HRT of 18 hours, and the AF reactor showed a removal efficiency of $63 \%$, respectively. These previous studies show a low removal efficiency and moreover, there is a need to develop a new process which would elevate removal efficiency of the stated parameters. Finally, the reactors of the 3 pilot-scale were not fitted with a heat inducing device which would regulate the temperature inside the anaerobic treatment reactors. In some cases it would be wise to explore the effect of heat has on an anaerobic treatment used in the treatment of poultry wastewater.

\section{B. Activated Sludge Processes}

Activated sludge (AS) process methods utilizes a combination of aeration and a biological floc composed of bacteria and protozoa. The AS process uses aerobic micro-organisms that can degrade pollutants and agglomerate them by flocculation [30]. A study of an evaluation of the activated process (AS) used in the treatment of PSW effluent by kinetic model simulation [31], the AS reactor at $26^{\circ} \mathrm{C}$ yielded a COD removal efficiency of $93.5 \%$ up to $97.2 \%$ respectively. Carvalho [32] evaluated the role of the AS system in the removal of pollutants present in the PSW effluent. The results indicated that sorption to sludge and wastewater organic matter was responsible for the removal of drug pollutants. The study of AS reactor with $100 \mu \mathrm{g} / \mathrm{L}$ initial drug pollutants present in the PSW effluent yielded removal rates of up to $68 \%$ enrofloxacin (ENR) and 77\% tetracycline (TET). The latter study results are not impressive as one would expect them to be, there was no information on the dosage of AS. Going forward, there would be a need to study the effect of dosage of AS on the treatment of PSW effluent.

\section{TYPES OF BIO-REACTORS}

There are a wide variety of anaerobic digesters which operate in different ways depending on the design specifications and material construction of each digester. Anaerobic digesters are divided into three basic categories, namely; passive systems, low rate systems and high rate system. In addition to the three categories listed in the latter, there is also an up-flow anaerobic sludge blanket (UASB), static granular bed reactor (SGBR),

and expanded granular sludge bed reactors (EGSB). In the UASB the influent enters the digester from the bottom toward the top in an upward flow direction passing a sludge granule blanket which filters and treats the wastewater as it flows through it [33]. The SGBR is a new reactor which has no mixing, but rather utilizes an anaerobic biofilter coupled with granules [34]. Lastly, the EGSB is similar to the UASB reactor with a high recycle ratio of the effluent stream to the influent feed stream [35].

(A)

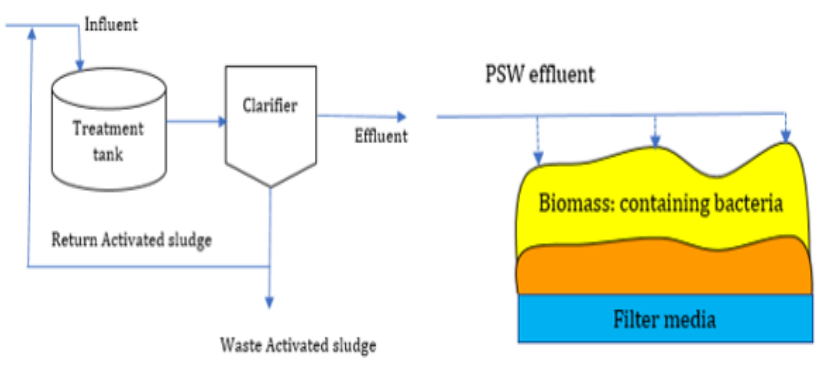

Fig. 2. Biological treatment: Suspended growth (A) \& Attached growth processes (B).

\section{TYPES OF BIO-REACTORS}

There are a wide variety of anaerobic digesters which operate in different ways depending on the design specifications and material construction of each digester. Anaerobic digesters are divided into three basic categories, namely; passive systems, low rate systems and high rate system. In addition to the three categories listed in the latter, there is also an up-flow anaerobic sludge blanket (UASB), static granular bed reactor (SGBR), and expanded granular sludge bed reactors (EGSB). In the UASB the influent enters the digester from the bottom toward the top in an upward flow direction passing a sludge granule blanket which filters and treats the wastewater as it flows through it [33]. The SGBR is a new reactor which has no mixing, but rather utilizes an anaerobic biofilter coupled with granules [34]. Lastly, the EGSB is similar to the UASB reactor with a high recycle ratio of the effluent stream to the influent feed stream [35].

\section{1) Up-flow Anaerobic Sludge Blanket (UASB)}

In the up-flow anaerobic sludge blanket (UASB) process, the wastewater enters at the bottom of the reactor and flows upward. There are micro-organisms in the sludge layer that degrade organic matter present in the PSW effluent. In one study, an evaluation of the performance and stability of a PSW treatment plant which utilized the UASB reactor with organic loading rates of $1.6 \pm 0.4 \mathrm{~kg} \mathrm{COD} / \mathrm{m} 3$ day and velocities of $0.3 \pm 0.1 \mathrm{~m} / \mathrm{h}$ was done. The results showed a total chemical oxygen demand (TCOD) and soluble chemical oxygen demand (SCOD) of up to $67 \%$ and $85 \%$ [36].

\section{2) Expanded Granular Sludge Bed (EGSB)}

The expanded granular sludge bed (EGSB) reactor is an adaptation of the UASB reactor with a distinguishing recirculation stream of the outlet effluent to the feed influent 
[37]. EGSB reactors utilize a fully or partially expanded bed granules of sludge where the wastewater gets to be treated as it passes through. The recirculation stream promotes bed fluidization of the granular sludge and like-wise there are micro-organisms present in the sludge which degenerate organic matter. The performance of a rapid start-up of the EGSB reactor by using brewery wastewater as a sludge in the treatment of wastewater was conducted [38]. The results of the study depicted that the sludge could develop faster within a period of 10 days in the EGSB reactor with little detached granules. Removal efficiencies of up to $72.9 \%$ of COD with a hydraulic retention time (HRT) of $12.1 \mathrm{hrs}$.

\section{3) Static Granular Bed Reactor (SGBR)}

The static granular bed reactor (SGBR) is a reactor which has no mixing mechanism but rather it has a down-flow system which is fitted with static granules and sludge that serve as a biodegrading medium. The SGBR reactor has a wide range of advantages which include the simplicity of operation and the production of high quality effluent [39]. A study of the SGBR was employed in the treatment of PSW effluent with an intention of evaluating two processes using anaerobic non-granular and granular biomass [40]. The study showed that both processes were highly efficient in the removal of COD with values above $95 \%$. Research treatment of wastewater by using a pilot SGBR reactor with organic loading rates between 0.63 to $9.72 \mathrm{~kg} / \mathrm{m} 3 / \mathrm{d}$ and a hydraulic retention time (HRT) of 9 to 48 hrs was performed. In the latter study removal efficiencies of COD, BOD5 above $90 \%$ and a TSS above $80 \%$ was achieved respectively [41]. Moreover, in another study of a SGBR fitted with pea gravel coupled with activated sludge from brewery proved a COD removal efficiency above $90 \%$ with a HRT range of 5 to 36 hrs [42].

\section{MATERIALS AND SYSTEM DESIGN}

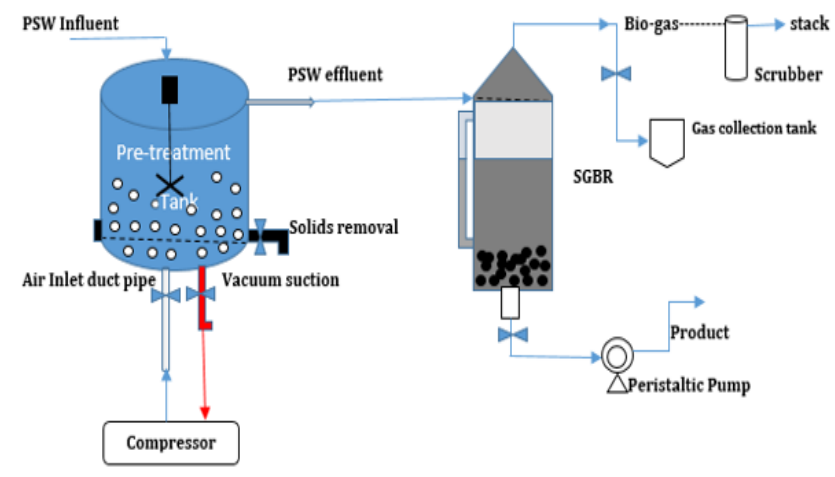

Fig. 3. Process schematic diagram of poultry slaughterhouse wastewater treatment (pilot plant).

The pilot plant is designed of the following specifications; 25 L mixing pre-treatment tank, clear PVC (SGBR) reactor of $5 \mathrm{~L}$, and $5 \mathrm{~L} / \mathrm{hrs}$ peristaltic pump operating at 10 Bar max. PSW influent is fed in the pre-treatment tank is treated with bacteria grown and isolated poultry effluent ponds. However, the PSW effluent product from the pre-treatment is fed in the subsequent stage of SGBR for further processing. The SGBR reactor is fitted with granules and the effluent is treated using activated sludge obtained from brewery. Analysis of influent and effluent samples before and after the pre-treatment stage and the SGBR bioreactor are performed in order to evaluate removal efficiency of COD, BOD, FOG, TSS, and $\mathrm{pH}$. The reduction of the amount of FOG in the pre-treatment stage and as well as the reduction of COD in the effluent discharged by the SGBR determine the pilot plant performance. Lastly, an evaluation of how inoculated biological enzymes influence the degradation of poultry slaughterhouse wastewater is performed. The current set up of the pilot plant has been opted for against other processes because it eco-friendly, electricity costs is low, and it generates by products such as methane gas and carbon-dioxide.

\section{Motivation FOR REACTOR SELECTION}

An effect of enzymatic pre-treatment by using pancreatic lipase proved to reduce pork fat present in wastewater; however, the effect enzymatic pre-treatment was never tested under anaerobic conditions [8]. In the latter study it showed that there is a remaining challenge that stems from evaluation of enzymes under anaerobic conditions. Additionally, it is worth noting that most of current designs of pre-treatment process lack a solids removal points and screens which are fitted at the bottom of the tank. It remains to be seen whether the use of a solids removal point would or would not disturb enzymatic activity after the pretreatment step. Generally, the screens serve a purpose of FOG \& other large particle removal when placed under vacuum suction. Lastly, it would be interesting to evaluate how the inoculated biological enzymes, isolated from PSW ponds, influence the degradation of poultry slaughterhouse wastewater. The current set up of the pilot plant has been opted for against other processes because it is fitted with a solids removal point, it is also fitted with screens at the bottom, it is eco-friendly, electricity costs are low, and it would permit a collection of by products such as methane gas and carbon-dioxide. Anaerobic bacteria gets survival from the food or nutrients (solids) instead of oxygen, and in most cases the process is advantageous in that it produces a reduced volume of sludge, high organic matter removal and high methane gas production it as well [43]. The methane gas produced from the process, if collected, can be used as a source of energy which can make it economically viable. Effluent discharged from PSW factories can also be treated cheaply and more effectively when employing the above pilot plant set up.

\section{CONCLUSION}

The efficiency of poultry slaughterhouse wastewater treatment is dependent on the set-up and design of process. The presented reviewed studies of different wastewater treatment processes show a diminishing removal efficiency. There is a need of the research to be conducted because of its novelty of employing, in the pre-treatment step, bacterium strains obtained from poultry ponds. Furthermore, the process of biological pre-treatment coupled with the use of SGBR inoculated with activated sludge is highly recommended.

\section{ACKNOWLEDGMENTS}

Acknowledgment goes to Cape Peninsula University of 
Technology (CPUT), Bioresource Engineering Research Group (BioERG) and supervisors of the research.

\section{REFERENCES}

[1] Bustillo-Lecompte, C., \& Mehrvar, M. (2017). Slaughterhouse Wastewater Treatment, Management and Resource Recovery. Physico-Chemical Wastewater Trestment and Resources Recovery, (May). Available: https://doi.org/10.5772/65499

[2] De Nardi, I. R., Del Nery, V., Amorim, A. K. B., dos Santos, N. G., \& Chimenes, F. (2011). Performances of SBR, chemical-DAF and UV disinfection for poultry slaughterhouse wastewater reclamation. Desalination, 269(1-3), 184-189. https://doi.org/10.1016/j.desal.2010.10.060

[3] Klaucans, E., \& Sams, K. (2018). Problems with Fat, Oil, and Grease (FOG) in Food Industry Wastewaters and Recovered FOG Recycling Methods Using Anaerobic Co-Digestion: A Short Review. Key Engineering Materials, (February), 61-68. https://doi.org/10.4028/www.scientific.net/KEM.762.61

[4] Rusten, B., Siljudalen, J. G., Wien, A., \& Eidem, D. (1998). Biological pretreatment of poultry processing wastewater. Water Science and Technology, 38(4-5), 19-28. https://doi.org/10.2166/wst.1998.0572

[5] Oh, J. H., Park, J., \& Ellis, T. G. (2015). Performance of on-site pilot static granular bed reactor (SGBR) for treating dairy processing wastewater and chemical oxygen demand balance modeling under different operational conditions. Bioprocess and Biosystems Engineering, 38(2), 353-363. https://doi.org/10.1007/s00449-014-1275-5

[6] Bruice T.C. and Benkovic S.J. (2000). Chemical basis for enzyme catalysis. Biochemistry 39, 6267-6274. https://doi.org/10.1021/bi0003689

[7] Tang, F. E., \& Tong, C. W. (2011). A Study of the Garbage Enzyme's Effects in Domestic Wastewater. International Journal of Environmental, 5(12), 887-892.

[8] Masse, L., Kennedy, K. J., \& Chou, S. P. (2001). The effect of an enzymatic pretreatment on the hydrolysis and size reduction of fat particles in slaughterhouse wastewater. Chemical Technology and Biotechnology, 635(February), 629-635. https://doi.org/10.1002/jctb.428

[9] Damasceno, F. R. C., Cavalcanti-Oliveira, E. D., Kookos, I. K., Koutinas, A. A., Cammarota, M. C., \& Freire, D. M. G. (2018). Treatment of wastewater with high fat content employing an enzyme pool and biosurfactant: Technical and economic feasibility. Brazilian Journal of Chemical Engineering, 35(2), 531-542. https://doi.org/10.1590/0104-6632.20180352s20160711

[10] Natassia, J. C., Benedito, M. G., Simone, D. G., Ana, P. R. S., \& Glaucia, M. P. (2017). Use of biosurfactant surfactin produced from cassava wastewater for anaerobic treatment of effluent from a poultry slaughterhouse. African Journal of Biotechnology, 16(5), 224-231. https://doi.org/10.5897/AJB2016.15668

[11] Vijayakuma, S., \& Saravanan, V. (2015). Biosurfactants-Types, Sources and Applications. Research Journal of Microbiology, 10(5), 181-192. https://doi.org/10.3923/jm.2015.181.192

[12] Poremba, K., Gunkel, W., Lang, S., \& Wagner, F. (1991). Toxicity testing of synthetic and biogenic surfactants on marine microorganisms. Environmental Toxicology and Water Quality, 6(2), 157-163. https://doi.org/10.1002/tox.2530060205

[13] De Trebbau Acevedo, G., \& Mclnerney, M. J. (1996). Emulsifying activity in thermophilic and extremely thermophilic microorganisms. Journal of Industrial Microbiology, 16(1), 1-7. https://doi.org/10.1007/BF01569914

[14] Kosaric, N. (2001). Biosurfactants and Their Application for Soil Bioremediation. 39(4), 295-304.

[15] Wang, K., Li, W., Gong, X., Li, X., Liu, W., He, C., Wang, J. (2014). International Biodeterioration \& Biodegradation Biological pretreatment of tannery wastewater using a full-scale hydrolysis acidification system. International Biodeterioration \& Biodegradation, 95, 41-45 https://doi.org/10.1016/j.ibiod.2014.05.019
[16] El-gohary, F., Taw, A., \& Mahmoud, U. (2010). Comparative study between chemical coagulation / precipitation $(\mathrm{C} / \mathrm{P})$ versus coagulation / dissolved air fl otation ( $\mathrm{C} / \mathrm{DAF}$ ) for pre-treatment of personal care products (PCPs) wastewater. 252, 106-112. https://doi.org/10.1016/j.desal.2009.10.016

[17] Voutchkov, N., Consultants, W. G., \& Lahav, O. (2014). Journal Desalination Pretreatment Article Sep 2010. (December 2012).

[18] U.S. EPA. (2000). Wastewater Technology Fact Sheet Package Plants. United States Environmental Protection Agency, 1-7.

[19] He, L., Tan, T., Gao, Z., \& Fan, L. (2019). The Shock Effect of Inorganic Suspended Solids in Surface Runoff on Wastewater Treatment Plant Performance. International Journal of Environmental Research and Public Health, 16(3), 453. https://doi.org/10.3390/ijerph16030453

[20] Bustillo-Lecompte, Ciro F, \& Mehrvar, M. (2015). Slaughterhouse wastewater characteristics, treatment, and management in the meat processing industry: A review on trends and advances. Journal of Environmental Management, 161, 287-302. https://doi.org/10.1016/j.jenvman.2015.07.008

[21] Del Nery, V., de Nardi, I. R., Damianovic, M. H. R. Z., Pozzi, E., Amorim, A. K. B., \& Zaiat, M. (2007). Long-term operating performance of a poultry slaughterhouse wastewater treatment plant. Resources, Conservation and Recycling, 50(1), 102-114. https://doi.org/10.1016/j.resconrec.2006.06.001

[22] Coca, J., Gutierrez, G., \& Benito, J. (2011). Water Purification and Management (J. Coca-Prados \& G. Gutiérrez-Cervelló, eds.). Available: https://doi.org/10.1007/978-90-481-9775-0

[23] Satyanarayan, S., Ramakant, \& Vanerkar, A. P. (2005). Conventional Approach for Abattoir Wastewater Treatment. Environmental Technology, 26(4), 441-448. https://doi.org/10.1080/09593332608618554

[24] Kobya, M., Senturk, E., \& Bayramoglu, M. (2006). Treatment of poultry slaughterhouse wastewaters by electrocoagulation. Journal of Hazardous Materials, 133(1-3), 172-176. https://doi.org/10.1016/j.jhazmat.2005.10.007

[25] Pozo, R., Tas, D. O., Dulkadirog, H., Orhon, D., \& Diez, V. (2003). Biodegradability of slaughterhouse wastewater with high blood content under anaerobic and aerobic conditions. Chemical Technology and Biotechnology, 391(July 2002), 384-391. https://doi.org/10.1002/jctb.753

[26] Aziz, A., Basheer, F., Sengar, A., Ullah, S., \& Haq, I. (2019). Science of the Total Environment Biological wastewater treatment (anaerobic-aerobic) technologies for safe discharge of treated slaughterhouse and meat processing wastewater. Science of the Total Environment, 686, 681-708. https://doi.org/10.1016/j.scitotenv.2019.05.295

[27] León-Becerril, E., García-Camacho, J. E., Del Real-Olvera, J., \& López-López, A. (2016). Performance of an upflow anaerobic filter in the treatment of cold meat industry wastewater. Process Safety and Environmental Protection, 102, 385-391. https://doi.org/10.1016/j.psep.2016.04.016

[28] Del Nery, Valéria, Pozzi, E., Damianovic, M. H. R. Z., Domingues, M. R., \& Zaiat, M. (2008). Granules characteristics in the vertical profile of a full-scale upflow anaerobic sludge blanket reactor treating poultry slaughterhouse wastewater. Bioresource Technology, 99(6), 2018-2024 https://doi.org/10.1016/j.biortech.2007.03.019.

[29] Yousefi, Z., Behbodi, M., \& Ali Mohammadpour, R. (2018). Slaughterhouse wastewater treatment by combined anaerobic baffled reactor and anaerobic filter: study of OLR and HRT optimization in $\mathrm{ABR} / \mathrm{AF}$ reactors. Environmental Health Engineering and Management, 5(3), 137-142. https://doi.org/10.15171/EHEM.2018.19

[30] Bustillo-Lecompte, Ciro F, \& Mehrvar, M. (2015). Slaughterhouse wastewater characteristics, treatment, and management in the meat processing industry: A review on trends and advances. Journal of Environmental Management, 161, 287-302. https://doi.org/10.1016/j.jenvman.2015.07.008

[31] Hsiao, T. H., Huang, J. S., \& Huang, Y. I. (2012). Process kinetics of an activated-sludge reactor system treating poultry slaughterhouse wastewater. Environmental Technology (United Kingdom), 33(7), 829-835.

https://doi.org/10.1080/09593330.2011.597782 
[32] Carvalho, P. N., Pirra, A., Basto, M. C. P., \& Almeida, C. M. R. (2013). Activated sludge systems removal efficiency of veterinary pharmaceuticals from slaughterhouse wastewater. Environmental Science and Pollution Research, 20(12), 8790-8800. https://doi.org/10.1007/s11356-013-1867-7

[33] Lettinga, G., Velsen, A. F. M. V. A. N., \& Hobma, S. W. (1980). Use of the Upflow Sludge Blanket (USB) Reactor Concept for Biological Wastewater Treatment, Especially for Anaerobic Treatment. XXII, 699-734. https://doi.org/10.1002/bit.260220402

[34] Debik, E., \& Coskun, T. (2009). Bioresource Technology Use of the Static Granular Bed Reactor (SGBR) with anaerobic sludge to treat poultry slaughterhouse wastewater and kinetic modeling. Bioresource Technology, 100(11), 2777-2782. https://doi.org/10.1016/j.biortech.2008.12.058

[35] Zoutberg, G. R., \& Been, P. De. (1997). The biobed ® EGSB (expanded granular sludge bed) system covers shortcomings of the upflow anaerobic sludge industry. Water Science and Technology, 35(10), 183-187. https://doi.org/10.2166/wst.1997.0381

[36] Del Nery, Valéria, Pozzi, E., Damianovic, M. H. R. Z., Domingues, M. R., \& Zaiat, M. (2008). Granules characteristics in the vertical profile of a full-scale upflow anaerobic sludge blanket reactor treating poultry slaughterhouse wastewater. Bioresource Technology, 99(6), 2018-2024.. https://doi.org/10.1016/j.biortech.2007.03.019

[37] Kato, M. T., Field, J. A., Versteeg, P., \& Lettinga, G. (1994). Feasibility of expanded granular sludge bed reactors for the anaerobic treatment of low-strength soluble wastewaters. Biotechnology and Bioengineering, 44(4), 469-479. https://doi.org/10.1002/bit.260440410

[38] Dong, C. J., Pan, Q. Y., Lu, H. Y., \& Sun, Y. Q. (2013). Rapidly Start-Up and Performance of the EGSB Reactor Treating Actual Coking Wastewater when Seeded with Digestion Sludge. Advanced Materials Research, 726-731, 2567-2571. https://doi.org/10.4028/www.scientific.net/AMR.765-767.2567

[39] Oh, J. H., Park, J., \& Ellis, T. G. (2015). Performance of on-site pilot static granular bed reactor (SGBR) for treating dairy processing wastewater and chemical oxygen demand balance modeling under different operational conditions. Bioprocess and Biosystems Engineering, 38(2), 353-363. https://doi.org/10.1007/s00449-014-1275-5

[40] Debik, E., \& Coskun, T. (2009). Bioresource Technology Use of the Static Granular Bed Reactor (SGBR) with anaerobic sludge to treat poultry slaughterhouse wastewater and kinetic modeling. Bioresource Technology, 100(11), 2777-2782. https://doi.org/10.1016/j.biortech.2008.12.058

[41] Park, H. J., Chon, J. W., Lim, J. S., Seo, K. H., Kim, Y. J., Heo, E. J., Moon, J. S. (2015). Prevalence Analysis and Molecular Characterization of Salmonella at Different Processing Steps in Broiler Slaughter Plants in South Korea. Journal of Food Science, 80(12), M2822-M2826. https://doi.org/10.1111/1750-3841.13106

[42] Ellis, T. G., \& Evans, K. M. (2008). A new high rate anaerobic technology, the static granular bed reactor (SGBR), for renewable energy production from medium strength waste streams. WIT Transactions on Ecology and the Environment, 109, 141-150. https://doi.org/10.2495/WM080161

[43] Aziz, A., Basheer, F., Sengar, A., Ullah, S., \& Haq, I. (2019). Science of the Total Environment Biological wastewater treatment (anaerobic-aerobic) technologies for safe discharge of treated slaughterhouse and meat processing wastewater. Science of the Total Environment, 686, 681-708 https://doi.org/10.1016/j.scitotenv.2019.05.295

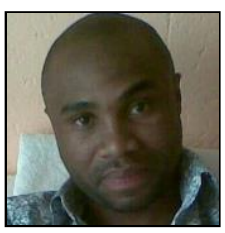

Derrick N. Dlamini is a member of Bioresource Engineering Research Group (BioERG), Cape Peninsula University of Technology. A South African researcher born in 16/08/1982 who has a B-Tech in Chemical Engineering (2007) from the University of Johannesburg, Gauteng, South Africa. He has worked as a Supervisor for 5 years in the production of base metals and 3 years in the sugar industry. Currently, he works at the Cape Peninsula University of Technology as a Laboratory Technician with an ambition of being a researcher.

Mr. Dlamini has won Safety awards and best MDW supervised team from his previous employment. He is currently pursuing a Master of Chemical Engineering in Chemical Engineering. 